\title{
Identification of Effective Leadership Indicators in Ghanaian Retail Banks Using AMOS Based Confirmatory Factor Analysis
}

\author{
Aminu Sanda \\ Department of Organization \& HRM \\ University of Ghana Business School \\ Accra, Ghana
}

\author{
John Kuada \\ Department of Business Studies \\ Aalborg University \\ Aalborg, Denmark
}

Received: January 25, 2019. Revised: March 28, 2021. Accepted: October 5, 2021. Published: November 16, 2021.

\begin{abstract}
In the light of the importance of banks to the economic growth process in Ghana, this study sought to identify the determinants of effective leadership style that is appreciated by employees in retail banking firms in Ghana, towards providing practitioners with crucial information that could enable them make informed decisions towards improving the workplace. Using data collected from employees in eleven firms which were analyzed using the AMOS programme, minimum was achieved for the leadership measurement model and the goodness of fit statistics showed that the overall model fit quite well to the data. Based on the findings from both factor analysis and Confirmatory factor analysis, the study established that managers of retail banks in Ghana could be perceived by their employees as good leaders if they give employees full credit for the work that they do. Handling employee issues very well and taking care of their complaints as well as putting in place systems for enhancing employees' career advancement into specialist departments or management positions are also perceived as good determinant of leadership. It is therefore hypothesized that managers of retail banks in Ghana could be perceived as good leaders by employees if they are seen as giving employees full credit for the work that they employees do at the workplace, handling employee issues very well and taking care of complaints brought up by employees, as well as putting in place systems for enhancing employees' career advancement into specialist departments or management positions are also perceived as good leaders.
\end{abstract}

Keywords-Leadership indicator; leadership style; confirmatory factor analysis; retail banks; Ghana

\section{INTRODUCTION}

The level of financial market development is known to have an impact on the economy of a nation. In this vein, the level of banking development and stock market liquidity also impact on the economy of a country. A long line of research posits a causal relationship between finance and economic growth ([1]). Evidence from both single-country and crosscountry studies suggests that economies with more developed financial markets begin to grow earlier, attain higher growth rates and achieve higher levels of per capita income than economies with less developed financial markets ([1]) .

Many empirical studies have also followed an earlier study by [2] in which differences across space and time was

This research was funded by the Growth \& Employment (GEP) Scheme "Strengthening Research Funding and Research Collaboration" as part of the Building Stronger Universities (BSU) - University of Ghana capacity building initiative. exploited to identify a cau sal link between finance and development, and recent research has focused on the mechanisms underlying that relationship. Reference [1] has also examined how banking institutions affect economic activity. This was based on the thought that financial intermediaries improve resource allocation and fund projects with higher rates of return by matching borrowers and lenders efficiently and by monitoring firm behavior ([3], [4], [5], [6], [7]). Thus the effective functioning of a country's financial system enhances the smooth implementation of its macroeconomic policies. Motivated by this view, governments in most African countries, including Ghana began to implement financial sector reforms starting in the late 1980s as part of their broad market reforms.

The major goals of these reforms are to build more efficient, competitive robust and deeper financial markets. Key aspect of the reforms include the (i) deregulation of the financial sub-sector through privatization of state-owned banks, (ii) influx of private banks, and (iii) registration of non-bank financial institutions, as well as the emergence of new products development and accompanying new processes enhancing financial service delivery by the banks. In the case of Ghana, these reforms have led to substantial growth of the banking sector. There were only 8 retail banks in the country in 1990. In 2009 , this number went up to 26 in 2009 , Ghana had 26 banks (up from 8 in 1990) with a total of 656 branches. In addition, there were also a number of financial service institutions such as insurance companies, investment houses, rural banks, stock exchange, cooperative credit unions, savings and loan institutions, mutual funds, and other microfinance institutions. The new generation private sector banks which were established during the last two decades have gained a substantial market share from the older state-owned banks ([8], [9]).

Managing rapid growth has always entailed enormous human resource challenges, even in advanced countries with larger pools of skilled employees and managerial talents. Companies operating in high growth sectors face the challenge of hiring and assimilating large numbers of new employees, providing new knowledge and skills to existing employees and addressing the needs for a rapid expansion of leadership capability. P roviding growth-oriented leadership requires 
attentiveness to employees, economic, social and emotional needs. The banking sector in Ghana is therefore faced with leadership and human resource management challenges. These include finding the right caliber of managers to employ, ensuring their commitment to their organizations and reducing their desire to switch to competitor companies, due to apparent dissatisfaction with their jobs. These challenges have been elaborately discussed in Western management literature. Studies have shown that job satisfaction impacts an employee's turnover intention, absenteeism and overall commitment to their organizations ([10]). It therefore impacts employees' overall contribution to organizational goal fulfilment and therefore organizational performance ([11], [12], [13]). The prevailing understanding is that when an employee is dissatisfied with his work, he is less committed and will look for opportunities to quit. If opportunities are unavailable, they may emotionally or mentally "withdraw" from the organization. Employee attrition is a major cost to rapidly growing companies. First, they lose the knowledge that the employee has built up over years of employment. Second there is the additional cost of replacing and training new employees. In the banking sector, where customer satisfaction depends very much on the relationships between employees and customers, this loss can be significant to some retail banks. Antecedents of job satisfaction and organizational commitment found in previous studies include ([14]), organizational culture ([15]), and national culture ([16]).

In the light of the importance of banks to the economic growth process in Ghana (just as in other countries) there is a great need to understand the leadership style of managers that is appreciated by employees in the management of the work place. This could lead to improvements in workplaces, helping managers to remain satisfied and continue in their jobs. From a practical standpoint, it is vital to provide practitioners with crucial information that could enable them to make informed decisions in the areas of recruitment, selection, promotion, and training. Thus, this study deals with issues that are potentially important for researchers and practitioners alike.

The purpose of this study was therefore to examine the influence of cultural values on job satisfaction and the organizational commitment of bank managers in Ghana. The main objective of this research is to improve academic and practitioners' understanding of the determinants of effective leadership style in the retail banking sector in Ghana.

\section{THEORETICAL CONSIDERATIONS}

Previous studies have suggested that there is a strong link between the development of a competitive financial sector in a country and its economic growth prospects. For example, [17], based on a cross-section sample of 41 countries for the period 1980-1990, found that increased concentration in banking markets generally depresses industrial growth, but also boosts the growth of industries that depend relatively heavily on external sources of finance. Similarly, based on data for regional banking markets in Italy, higher concentration has been found to promote firm creation in industries where the creditworthiness of entrepreneurs is difficult to assess ([18]). Conversely, [19] has found that more competition in banking markets raises the growth of industries that depend relatively heavily on external financing. This finding by [19] was contrasted by [20] who rather concluded that more competition in banking markets lowers the growth of industries that depend relatively heavily on external financing. This observation therefore reinforces the notion (supported by recent empirical evidence) that bank competition fosters industrial growth ([19]), and particularly, helps in the financing of private and small firms that are perceived to be engine of economic growth ([21]). This is based on the understanding that competitive systems may lead to easier access to external financing because, with more market power, banks are more inclined to invest in information acquisition and relationships with borrowers ([19]).

On the contrary, when banking systems are less competitive, hold-up problems may lead borrowers to be less willing to enter such relationships, thereby lowering the effective demand for external financing ([19]). Lesscompetitive banking systems are also perceived to be more costly and exhibit a lower quality of services, thereby lowering the effective demand for external financing and thus encouraging less growth ([22]). Against the background given above, there is the need to understand how bank management processes in Ghana can contribute to job satisfaction and organizational commitment and thereby lead to the improvement of the banks' relationships with their customers towards increased firm performance while contributing to the country's economic growth. One strand of management research that has a strong promise theoretical promise for the present study is the Person-Organization (PO) Fit framework. It highlights the compatibility between people and the organizations in which they work ([23]). This framework can be used to examine (a) how employee selection and career development can serve as a first step in developing a high performing banking industry culture, where employees show commitment to both their organizations and their external stakeholders (i.e. customers).

The PO Fit concept suggests that an individual's attitudes and behaviors are influenced by the extent to which the organization and the individual are similar or have a fit on certain characteristics ([24]). Typical characteristics that are examined the individual's and the environment's values, goals, and traits ([25], [26], [27], [28], [29], [30]). The fit between the individual and the organization has been related to various attitudinal and behavioral outcomes such as job satisfaction, organizational commitment, intention to quit, turnover, and task performance ([31], [32], [33], [34]). The fit between the individual and the organization with regard to organizational strategy ([24]) and organizational commitment (e.g., [35], [25], [36], [30], [37], [38], [39], [40]) have also been examined. However, research has not examined the fit between employee selection and career development with regard to organizational culture.

In the light of the above discussions, this study sought to hypothesize the dominant indicators perceived by employees as characterizing good leadership styles in retail banks in Ghana. Thus, our initial literature review suggested that the model presented in figure 1 be low could guide our empirical investigation. The indicator labels for the model are shown in table 1 . 


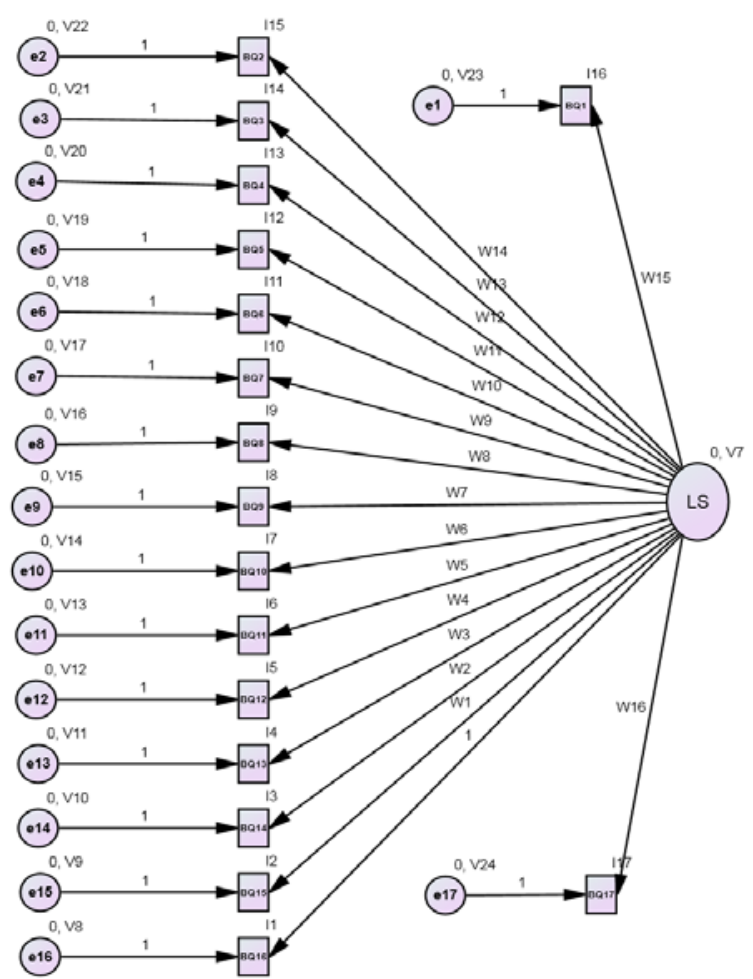

Fig. 1. Structured model of relationship between leadership style and indicator variables using AMOS graphics.

TABLE 1. INDICATOR VARIABLES OF LEADERSHIP STYLE IN RETAIL BANKS

\begin{tabular}{|l|c|}
\hline \multicolumn{1}{|c|}{ Measurable Factors } & $\begin{array}{c}\text { Label in } \\
\text { Model }\end{array}$ \\
\hline Supervisors and employees understanding each other. & $\mathrm{BQ} 1$ \\
\hline $\begin{array}{l}\text { Managers noticing employees in good ways upon doing } \\
\text { good jobs. }\end{array}$ & $\mathrm{BQ} 2$ \\
\hline Managers providing help to employees on hard problems. & $\mathrm{BQ} 3$ \\
\hline Managers giving good training to employees. & $\mathrm{BQ} 4$ \\
\hline Managers delegating work to staff members. & $\mathrm{BQ5}$ \\
\hline Supervisors giving employees full credit for the work done. & $\mathrm{BQ6}$ \\
\hline Managers handling employee issues very well. & $\mathrm{BQ7}$ \\
\hline Managers backing employees up with good administration. & $\mathrm{BQ}$ \\
\hline $\begin{array}{l}\text { Managers taking care of complaints brought up by } \\
\text { employees. }\end{array}$ & $\mathrm{BQ} 9$ \\
\hline Managers' competence in making decisions. & $\mathrm{BQ10}$ \\
\hline $\begin{array}{l}\text { Managers enhancing employees' career advancement into } \\
\text { specialist departments or management positions. }\end{array}$ & $\mathrm{BQ11}$ \\
\hline $\begin{array}{l}\text { Managers ensuring that staff members have full knowledge } \\
\text { of the firm's products/services. }\end{array}$ & $\mathrm{BQ12}$ \\
\hline $\begin{array}{l}\text { Managers ensuring that staff members acquire effective } \\
\text { client-customer relationship skills. }\end{array}$ & $\mathrm{BQ13}$ \\
\hline $\begin{array}{l}\text { Managers ensuring that staff members are fully trained in } \\
\text { how to work with maximum effect. }\end{array}$ & $\mathrm{BQ14}$ \\
\hline $\begin{array}{l}\text { Managers increasing the confidence, motivation and } \\
\text { commitment of staff. }\end{array}$ & $\mathrm{BQ15}$ \\
\hline $\begin{array}{l}\text { Managers providing staff with recognition, enhanced } \\
\text { responsibility and, the possibility of increased pay and } \\
\text { promotion. }\end{array}$ & $\mathrm{BQ} 16$ \\
\hline $\begin{array}{l}\text { Managers giving staff a feeling of personal satisfaction and } \\
\text { achievement }\end{array}$ & $\mathrm{BQ17}$ \\
\hline
\end{tabular}

\section{METHODOLOGY}

\section{A. Data Collection}

Data was sourced from eleven (11) financial institutions in Ghana that are engaged in retailing data. In order to gain an unhindered access to target employees, in these banks, the support and approval of top management for the study was firstly sought and obtained.

A stratified random sampling technique was then used to select the respondents from each of the retail banks. The stratification was based on the respondents' position in the firms (i.e. managerial and non-managerial. Data entailing seventeen (17) leadership style indicators was collected using a self-administering questionnaire.

The demographic characteristics of the respondents in terms of their gender, organizational status, age, highest educational level attained, and the number of years worked with the banks is highlighted below. The gender of the bank employees who served as study respondents is summarized in table 2 below.

TABLE 2. GENDER DISTRIBUTION OF STUDY PARTICIPANTS

\begin{tabular}{|l|c|c|c|c|}
\hline Gender & $\begin{array}{c}\text { Frequency } \\
\text { (N) }\end{array}$ & Percent & $\begin{array}{c}\text { Valid } \\
\text { Percent }\end{array}$ & $\begin{array}{c}\text { Cumulative } \\
\text { Percent }\end{array}$ \\
\hline Male & 146 & 51.8 & 51.8 & 51.8 \\
\hline Female & 136 & 48.2 & 48.2 & 100.0 \\
\hline Total & 282 & 100.0 & 100.0 & \\
\hline
\end{tabular}

The distribution shows that $51.8 \%(\mathrm{~N}=146)$ of the 282 study respondents were males while $48.2 \%(\mathrm{~N}=136)$ were females. Though it appears from this statistics that there were more males than females, the closeness of the percentage provides a fair sense of sample representation in terms of respondents' gender.

The stratification of the study respondents into managerial and non-managerial categories is highlighted in table 3 below.

TABLE 3. SUMMARY OF RESPONDENTS" POSITION IN THE BANKS

\begin{tabular}{|l|c|c|c|c|}
\hline Position & $\begin{array}{c}\text { Frequency } \\
(\mathbf{N})\end{array}$ & Percent & $\begin{array}{c}\text { Valid } \\
\text { Percent }\end{array}$ & $\begin{array}{c}\text { Cumulative } \\
\text { Percent }\end{array}$ \\
\hline Managerial & 57 & 20.2 & 20.2 & 20.2 \\
\hline Non-managerial & 225 & 79.8 & 79.8 & 100.0 \\
\hline Total & 282 & 100 & 100.0 & \\
\hline
\end{tabular}

The distribution shows that out of the sample 282 respondents, $20.2 \%(\mathrm{~N}=57)$ hold managerial status in the banks, while the remaining $79.8 \%(\mathrm{~N}=225)$ were general staff members with no managerial responsibilities. This distribution indicates a fair representation of span of control (supervisor employees) in the banks in where a manager is expected to directly supervise an average of five employees.

The age distribution of the study respondents is summarized in table 4 below. The distribution shows that majority $(61.7 \%)$ of the respondents were mid-career employees $(\mathrm{N}=174)$ whose age ranged from 30 years to 49 years. 
TABLE 4. AGE DISTRIBUTION OF STUDY PARTICIPANTS

\begin{tabular}{|c|c|c|c|c|}
\hline Age Range & $\begin{array}{c}\text { Frequency } \\
\text { (N) }\end{array}$ & Percent & $\begin{array}{c}\text { Valid } \\
\text { Percent }\end{array}$ & $\begin{array}{c}\text { Cumulative } \\
\text { Percent }\end{array}$ \\
\hline 20-29 years & 101 & 35.8 & 35.8 & 35.8 \\
\hline 30-39 years & 120 & 42.6 & 42.6 & 78.4 \\
\hline 40-49 years & 54 & 19.1 & 19.1 & 97.5 \\
\hline 50-59 years & 7 & 2.5 & 2.5 & 100.0 \\
\hline Total & 282 & 100.0 & 100.0 & \\
\hline
\end{tabular}

One hundred and one $(35.8 \%)$ of the respondents were also in the prime of their careers with age that ranged from 20 years to 29 years. Only $2.5 \%(\mathrm{~N}=7)$ of the 260 study respondents were at the epic stage of their careers with age range of 50 years to 59 years. The study respondents thus represent a fair collective of matured bank employees.

The categorization of the highest level of educational qualification attained by the study participants is highlighted in table 5 below.

TABLE 5. SUMMARY OF STUDY PARTICIPANTS' LEVELS OF EDUCATION

\begin{tabular}{|l|c|c|c|c|}
\hline $\begin{array}{c}\text { Level of } \\
\text { Education }\end{array}$ & $\begin{array}{c}\text { Frequency } \\
\text { (N) }\end{array}$ & Percent & $\begin{array}{c}\text { Valid } \\
\text { Percent }\end{array}$ & $\begin{array}{c}\text { Cumulative } \\
\text { Percent }\end{array}$ \\
\hline Certificate & 5 & 1.8 & 1.8 & 1.8 \\
\hline Diploma & 16 & 5.7 & 5.7 & 7.4 \\
\hline Degree & 160 & 56.7 & 56.7 & 64.2 \\
\hline Post graduate & 94 & 33.3 & 33.3 & 97.5 \\
\hline Other & 7 & 2.8 & 2.8 & 100 \\
\hline Total & 282 & 100.0 & 100.0 & \\
\hline
\end{tabular}

The distribution in table 4 above shows that majority of the respondents were highly educated as it is indicated by a total of $90.0 \%(\mathrm{~N}=254)$ respondents who are university degree holders education, and the $7.5 \%(\mathrm{~N}=21)$ who are diploma and certificate holders.

The categorization of the number of years the study participants have been working in their organizations is summarized in table 6 below.

TABLE 6. SUMMARY OF STUDY PARTICIPANTS WORK YEARS IN THE BANKS

\begin{tabular}{|l|c|c|c|c|}
\hline $\begin{array}{c}\text { Working } \\
\text { Years }\end{array}$ & $\begin{array}{c}\text { Frequency } \\
\text { (N) }\end{array}$ & Percent & $\begin{array}{c}\text { Valid } \\
\text { Percent }\end{array}$ & $\begin{array}{c}\text { Cumulative } \\
\text { Percent }\end{array}$ \\
\hline $\begin{array}{c}\text { Less than I } \\
\text { year }\end{array}$ & 33 & 11.7 & 11.7 & 11.7 \\
\hline 1-2 years & 59 & 20.9 & 20.9 & 32.6 \\
\hline 3-4 years & 76 & 27.0 & 27.0 & 59.6 \\
\hline 5-6 years & 50 & 17.7 & 17.7 & 77.3 \\
\hline 7-8 years & 36 & 12.8 & 12.8 & 90.1 \\
\hline 9-10 years & 10 & 3.5 & 3.5 & 93.6 \\
\hline 11+ years & 18 & 6.4 & 6.4 & 100.0 \\
\hline Total & 282 & 100.0 & 100.0 & \\
\hline
\end{tabular}

The distribution in table 5 above shows that a vast majority of the respondents, comprising about $67.4 \%(\mathrm{~N}=190)$ have been working with their banks for a time period of not less than three years. As it is deducible from the table, $22.7 \%(\mathrm{~N}=64)$ have worked in their banks for a time period of more than seven years, while $44.7 \%(\mathrm{~N}=126)$ have worked for a period ranging from three years to six years. Only $11.7 \%(\mathrm{~N}=33)$ of the respondents have spent less than a year in their organizations. This implies that on the average, the study participants are fairly knowledgeable about the managerial and structural characteristics of their work environments.

\section{B. Data Analysis}

Both factor analysis and confirmatory factor analysis were conducted to test the measurement model by using the analysis of moment structures (AMOS) programme to estimate the factor score weights (regression weights or path coefficients) for the indicator variables (observed variables) relating to the latent variable (i.e. leadership style). The AMOS graphic statistical software was used as the analytical tool.

\section{RESULTS AND DISCUSSION}

In this section, the measured factors (regression weights) predictive of leadership style, organizational culture, national culture, employee characteristics, job satisfaction, organizational commitment, and organizational performance are analyzed, and the factors with the requisite predictive characteristics are determined. At the start of the analysis, the predicted model structure (see figure 1) outlining the relationship among the various model components (i.e. leadership style, organizational culture, national culture, employee characteristics, job satisfaction, organizational commitment, and organizational performance) was loaded into the AMOS software. The AMOS software recognized each of these components as latent variables and thus was not able to provide a model fit for the predicted model structure (i.e. figure 1). In this respect therefore, each of the latent variables in the predicted model structure was model-fitted to its measurable factors in the AMOS software. This allowed for the performance of confirmatory factor analysis and the subsequent estimation of individual factor loadings which weights were analyzed and used to characterize the respective components of the predicted model structure from latent variables into measured variables.

In the confirmatory factor analysis, the factor score weights (i.e. regression estimates) for each factor in the respective scales (i.e. leadership style, organizational culture, national culture, employee characteristics, job satisfaction, organizational commitment, and organizational performance) constituting the relationship outlined by the model in figure 1) were firstly generated from the AMOS software and then appraised in order to identify the most appropriate factor that could be used as the most representative in testing relationship professed in the predicted model (figure 1).

\section{A. Factor Analysis of indicators Predictive Relationship with Leadership Style in Retail Banks}

Though loadings in the logic of SEM is to start with theory, including labeled constructs, and then test for model fit in confirmatory factor analysis, these loadings can be used, as in factor analysis, to impute labels to the latent variables. The unstandardized and standardized model-fits generated by the AMOS software for "leadership style" as a latent variable and its indicator variables (measureable factors) are shown in figures 2 and 3 below. The model fit summary is also shown in table 7 . 


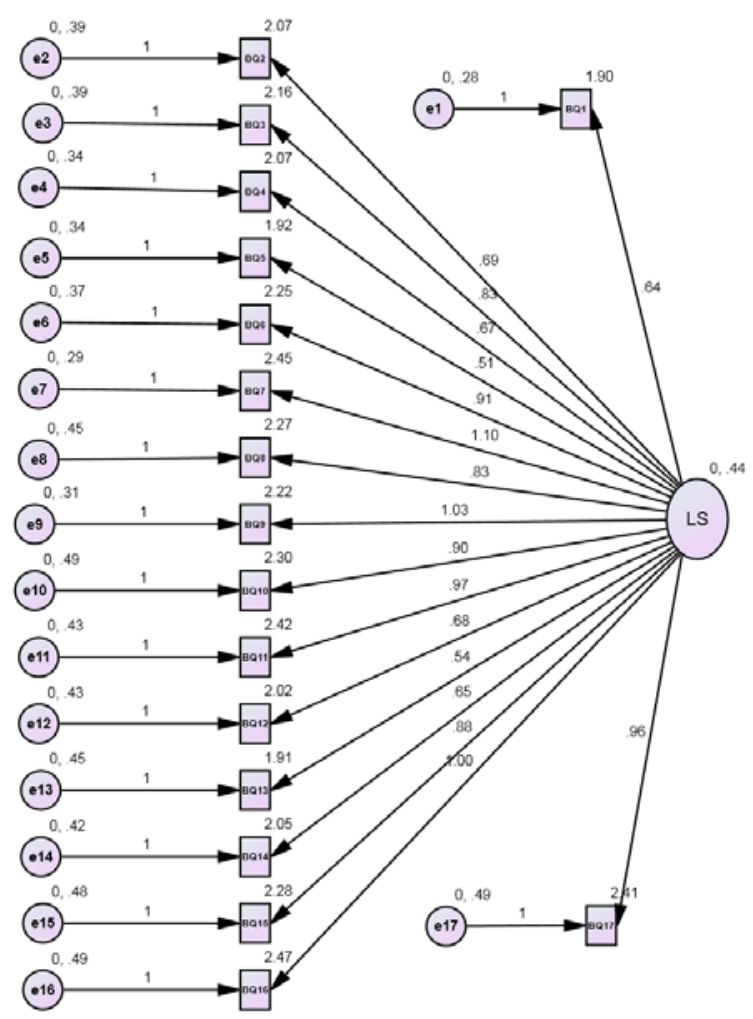

Fig. 2. AMOS graphics generated path diagram showing unstandardized indicator loadings for predicting effective leadership style in retail banks

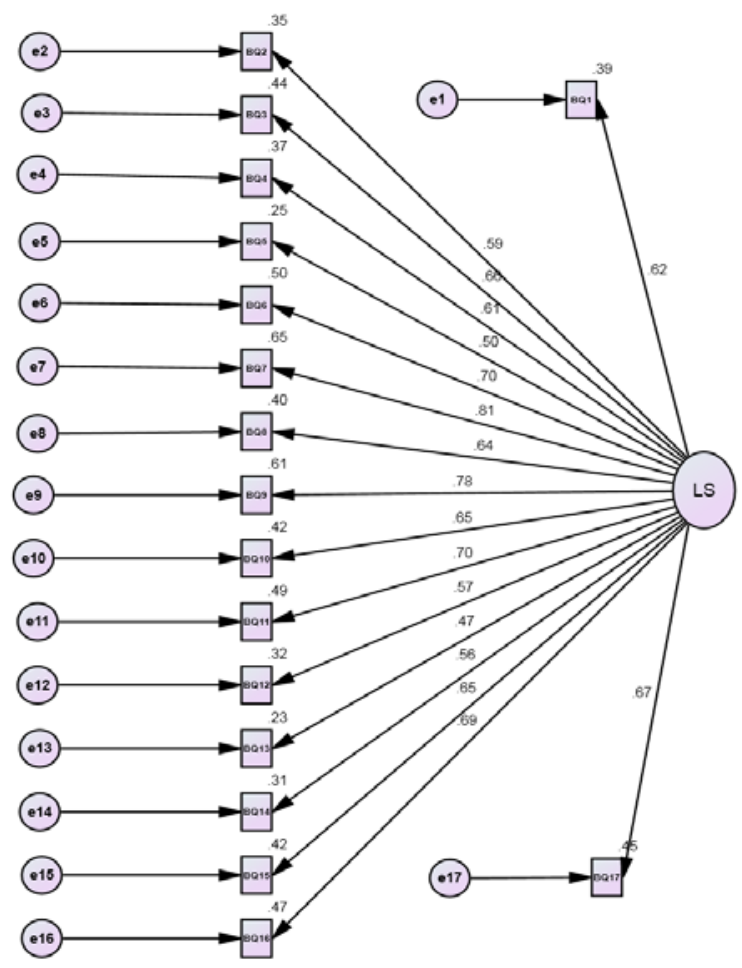

Fig. 3. AMOS graphics generated path diagram showing standardized indicator loadings for predicting effective leadership style in retail banks
TABLE 7. MODEL FIT SUMMARY FOR STRUCTURED MODEL CMIN

\begin{tabular}{|l|c|c|c|c|c|}
\hline \multicolumn{1}{|c|}{ Model } & $\begin{array}{c}\text { NPA } \\
\text { R }\end{array}$ & CMIN & DF & P & $\begin{array}{c}\text { CMIN/ } \\
\text { DF }\end{array}$ \\
\hline Default model & 51 & 556.213 & 119 & 0.000 & 4.674 \\
\hline Saturated model & 170 & .000 & 0 & & \\
\hline $\begin{array}{l}\text { Independence } \\
\text { model }\end{array}$ & 17 & 2448.451 & 153 & 0.000 & 16.003 \\
\hline
\end{tabular}

BASELINE COMPARISONS

\begin{tabular}{|l|c|c|c|c|c|}
\hline \multicolumn{1}{|c|}{ Model } & $\begin{array}{c}\text { NFI } \\
\text { Delta1 }\end{array}$ & $\begin{array}{c}\text { RFI } \\
\text { rho1 }\end{array}$ & $\begin{array}{c}\text { IFI } \\
\text { Delta2 }\end{array}$ & $\begin{array}{c}\text { TLI } \\
\text { rho2 }\end{array}$ & CFI \\
\hline Default model & 0.773 & 0.708 & 0.812 & 0.755 & 0.810 \\
\hline Saturated model & 1.000 & & 1.000 & & 1.000 \\
\hline $\begin{array}{l}\text { Independence } \\
\text { model }\end{array}$ & 0.000 & 0.000 & 0.000 & 0.000 & 0.000 \\
\hline
\end{tabular}

PARSIMONY-ADJUSTED MEASURES

\begin{tabular}{|l|c|c|c|}
\hline \multicolumn{1}{|c|}{ Model } & PRATIO & PNFI & PCFI \\
\hline Default model & 0.778 & 0.601 & 0.630 \\
\hline Saturated model & 0.000 & 0.000 & 0.000 \\
\hline Independence model & 1.000 & 0.000 & 0.000 \\
\hline
\end{tabular}

NCP

\begin{tabular}{|l|c|c|c|}
\hline \multicolumn{1}{|c|}{ Model } & NCP & LO 90 & HI 90 \\
\hline Default model & 437.213 & 367.622 & 514.338 \\
\hline Saturated model & 0.000 & 0.000 & 0.000 \\
\hline Independence model & 2295.451 & 2138.863 & 2459.404 \\
\hline
\end{tabular}

FMIN

\begin{tabular}{|l|c|c|c|c|}
\hline \multicolumn{1}{|c|}{ Model } & FMIN & F0 & LO 90 & HI 90 \\
\hline Default model & 1.979 & 1.556 & 1.308 & 1.830 \\
\hline Saturated model & 0.000 & 0.000 & 0.000 & 0.000 \\
\hline Independence model & 8.713 & 8.169 & 7.612 & 8.752 \\
\hline
\end{tabular}

RMSEA

\begin{tabular}{|l|c|c|c|c|}
\hline \multicolumn{1}{|c|}{ Model } & RMSEA & LO 90 & HI 90 & PCLOSE \\
\hline Default model & 0.114 & 0.105 & 0.124 & 0.000 \\
\hline $\begin{array}{l}\text { Independence } \\
\text { model }\end{array}$ & 0.231 & 0.223 & 0.239 & 0.000 \\
\hline
\end{tabular}

AIC

\begin{tabular}{|l|c|c|c|c|}
\hline \multicolumn{1}{|c|}{ Model } & AIC & BCC & BIC & CAIC \\
\hline Default model & 658.213 & 665.194 & & \\
\hline Saturated model & 340.000 & 363.270 & & \\
\hline $\begin{array}{l}\text { Independence } \\
\text { model }\end{array}$ & 2482.451 & 2484.778 & & \\
\hline
\end{tabular}

\section{ECVI}

\begin{tabular}{|l|c|c|c|c|}
\hline \multicolumn{1}{|c|}{ Model } & ECVI & LO 90 & HI 90 & MECVI \\
\hline Default model & 2.342 & 2.095 & 2.617 & 2.367 \\
\hline Saturated model & 1.210 & 1.210 & 1.210 & 1.293 \\
\hline $\begin{array}{l}\text { Independence } \\
\text { model }\end{array}$ & 8.834 & 8.277 & 9.418 & 8.843 \\
\hline
\end{tabular}

HOELTER

\begin{tabular}{|l|c|c|}
\hline \multicolumn{1}{|c|}{ Model } & HOELTER & HOELTER \\
& $\mathbf{0 . 0 5}$ & $\mathbf{0 . 0 1}$ \\
\hline Default model & 74 & 80 \\
\hline Independence model & 21 & 23 \\
\hline
\end{tabular}


As it is highlighted in figure 1 above, seventeen (17) predictive indicators were tested per the data collected and minimum was achieved for the model. Based on the goodness of fit statistics, it is evident that the overall model fit does not appear quite good. This is because the estimated $\chi 2$ of 556.213 $(\mathrm{df}=119)$ is so large that the null hypothesis of a good fit is rejected at the 0.05 level $(\mathrm{p}<.000)$. Additionally, the estimated Root Mean Square Error of Approximation (RMSEA) of .114 is also large, and thus rejects the null hypothesis of a good fit at the .05 level $(p<0.000)$. Even though the estimate for the Comparative Fit Index (CFI) of 0.810 indicates an acceptance of the null hypothesis, it also suggests that the model fit to the data is questionable. Therefore, the proposed one factor model (figure 1) shows a poor fit and as such needs to be modified somehow. In this regard, factor analysis is carried out to identify the indicator variables that have significant relationships with the latent variable (i.e. leadership style). The standardized regression estimate obtained from AMOS which represents the factor loadings (i.e. indicator coefficients) associated with the arrows from latent variables to the respective indicator variables are highlighted in table 8 below.

By convention, the indicators should have loadings of 0.7 or higher on the latent variable ([41] for them to be significant. In this regard therefore, based on the results highlighted in table 8 above, the following indicators could be deemed as not having significant predictive relationship with the latent variable (i.e. leader style); (i) managers noticing employees in good ways upon doing good jobs $(\mathrm{r}=0.807, \alpha=0.651)$; (ii) managers providing help to employees on hard problems $(\mathrm{r}=$ $0.665, \alpha=0.442$ ), (iii) giving good training to employees ( $r=$ $0.610, \alpha=0.372$ ), (iv) managers delegating work to staff members $(\mathrm{r}=0.503, \alpha=0.253)$, (v) managers backing employees up with good administration $(r=0.635, \alpha=0.404)$, (vi) managers ensuring that staff members acquire effective client-customer relationship skills ( $\mathrm{r}=0.475, \alpha=0.225$ ), (vii) managers ensuring that staff members are fully trained in how to work with maximum effect $(r=0.559, \alpha=0.312)$, (viii) managers providing staff with recognition, enhanced responsibility and, the possibility of increased pay and promotion ( $\mathrm{r}=0.688, \alpha=0.473$ ), (ix) managers giving staff a feeling of personal satisfaction and achievement $(\mathrm{r}=0.672, \alpha=$ $0.451)$, (x) managers increasing the confidence, motivation and commitment of staff ( $\mathrm{r}=0.648, \alpha=0.420$ ), (xi) managers ensuring that staff members have full knowledge of the firm's products/services $(\mathrm{r}=0.568, \alpha=0.322)$, (xii) supervisors and employees understanding each other $(r=0.807, \alpha=0.651)$, and (xiii) manager's competence in making decisions $(\mathrm{r}=$ $0.651, \alpha=0.424$ ). On the other hand, the following four (4) indicator variables with loadings of 0.7 and higher as indicated in table 8 above are identified and used to modify the one factor model (figure 1) which was then retested using Confirmatory Factor Analysis; BQ7 - Supervisors giving employees full credit for the work done $(r=0.807, \alpha=0.651)$; BQ6 - Managers handling employee issues very well $(\mathrm{r}=$ 0.704, $\alpha=0.491$ ); BQ9 - Managers taking care of complaints brought up by employees ( $\mathrm{r}=0.779, \alpha=0.606)$; and BQ11 Managers enhancing employees' career advancement into specialist departments or management positions $(\mathrm{r}=0.702, \alpha=$ 0.493).
TABLE 8. STANDARDIZED REGRESSION ESTIMATES (FACTOR LOADINGS) FROM LATENT VARIABLE (LEADERSHIP STYLE) TO INDICATOR VARIABLES

\begin{tabular}{|c|c|c|c|}
\hline Indicator Variables & $\begin{array}{l}\text { Indicator } \\
\text { Label in } \\
\text { Model }\end{array}$ & $\begin{array}{l}\text { Standardized } \\
\text { Regression } \\
\text { Estimate } \\
\text { (indicator } \\
\text { coefficient) }\end{array}$ & $\begin{array}{c}\text { Squared } \\
\text { Multiple } \\
\text { Correlations }\end{array}$ \\
\hline $\begin{array}{l}\text { Supervisors and employees } \\
\text { understanding each other. }\end{array}$ & BQ1 & 0.625 & 0.391 \\
\hline $\begin{array}{l}\text { Managers noticing employees } \\
\text { in good ways upon doing } \\
\text { good jobs. }\end{array}$ & BQ2 & 0.592 & 0.351 \\
\hline $\begin{array}{l}\text { Managers providing help to } \\
\text { employees on hard problems. }\end{array}$ & BQ3 & 0.665 & 0.442 \\
\hline $\begin{array}{l}\text { Managers giving good } \\
\text { training to employees. }\end{array}$ & BQ4 & 0.610 & 0.372 \\
\hline $\begin{array}{l}\text { Managers delegating work to } \\
\text { staff members. }\end{array}$ & BQ5 & 0.503 & 0.253 \\
\hline $\begin{array}{l}\text { Supervisors giving employees } \\
\text { full credit for the work done. }\end{array}$ & BQ6 & 0.704 & 0.495 \\
\hline $\begin{array}{l}\text { Managers handling employee } \\
\text { issues very well. }\end{array}$ & BQ7 & 0.807 & 0.651 \\
\hline $\begin{array}{l}\text { Managers backing employees } \\
\text { up with good administration. }\end{array}$ & BQ8 & 0.635 & 0.404 \\
\hline $\begin{array}{l}\text { Managers taking care of } \\
\text { complaints brought up by } \\
\text { employees. }\end{array}$ & BQ9 & 0.779 & 0.606 \\
\hline $\begin{array}{l}\text { Managers' competence in } \\
\text { making decisions. }\end{array}$ & BQ10 & 0.651 & 0.424 \\
\hline \begin{tabular}{|l|} 
Managers enhancing \\
employees' career \\
advancement into specialist \\
departments or management \\
positions. \\
\end{tabular} & BQ11 & 0.702 & 0.493 \\
\hline $\begin{array}{l}\text { Managers ensuring that staff } \\
\text { members have full knowledge } \\
\text { of the firm's } \\
\text { products/services. }\end{array}$ & BQ12 & 0.568 & 0.322 \\
\hline \begin{tabular}{|l|} 
Managers ensuring that staff \\
members acquire effective \\
client-customer relationship \\
skills.
\end{tabular} & BQ13 & 0.475 & 0.225 \\
\hline $\begin{array}{l}\text { Managers ensuring that staff } \\
\text { members are fully trained in } \\
\text { how to work with maximum } \\
\text { effect. }\end{array}$ & BQ14 & 0.559 & 0.312 \\
\hline $\begin{array}{l}\text { Managers increase the } \\
\text { confidence, motivation and } \\
\text { commitment of staff. }\end{array}$ & BQ15 & 0.648 & 0.420 \\
\hline $\begin{array}{l}\text { Managers providing staff with } \\
\text { recognition, enhanced } \\
\text { responsibility and, the } \\
\text { possibility of increased pay } \\
\text { and promotion. }\end{array}$ & BQ16 & 0.688 & 0.473 \\
\hline $\begin{array}{l}\text { Managers giving staff a } \\
\text { feeling of personal } \\
\text { satisfaction and achievement }\end{array}$ & BQ17 & 0.672 & 0.451 \\
\hline
\end{tabular}

\section{B. Confirmatory Factor Analysis of indicators Predictive} Relationship with Leadership Style in Retail Banks

The confirmatory factor analysis step in SEM is a test of the meaningfulness of latent variables and their indicators. In this analysis, the meaningfulness of the latent variable (leadership style) and its indicators (i.e. BQ6, BQ7, BQ9 and $\mathrm{BQ} 11)$ is tested. The unstandardized and standardized model- 
fits generated by the AMOS software for the latent variable (leadership style) and the indicator variables (measureable factors) are shown in figures 4 and 5 below. The model fit summary is also shown in table 9 .

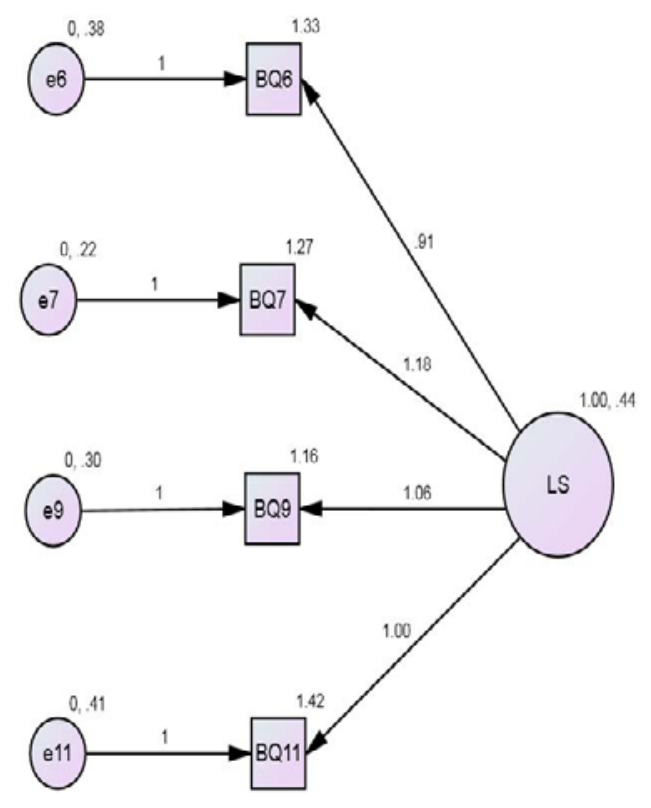

Fig. 4. AMOS graphics generated path diagram showing unstandardized indicator loadings in the modified model for predicting effective leadership style in retail banks.

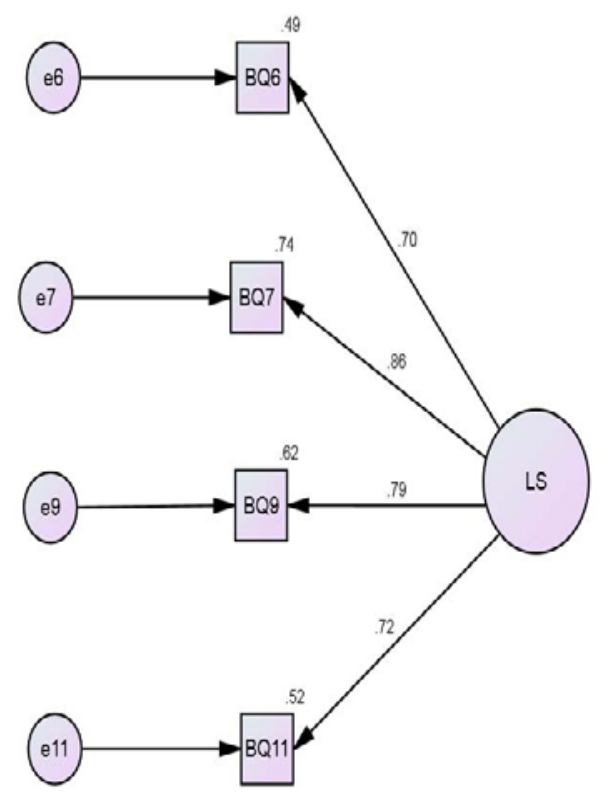

Fig. 5. AMOS graphics generated path diagram showing standardized indicator loadings in the modified model for predicting effective leadership style in retail banks
TABLE 9: MODIFIED MODEL FIT SUMMARY

CMIN

\begin{tabular}{|l|c|c|c|c|c|}
\hline \multicolumn{1}{|c|}{ Model } & NPAR & CMIN & DF & P & $\begin{array}{c}\text { CMIN/ } \\
\text { DF }\end{array}$ \\
\hline Default model & 12 & 1.645 & 2 & 0.439 & 0.823 \\
\hline Saturated model & 14 & 0.000 & 0 & & \\
\hline $\begin{array}{l}\text { Independence } \\
\text { model }\end{array}$ & 4 & 465.301 & 10 & 0.000 & 46.530 \\
\hline
\end{tabular}

BASELINE COMPARISONS

\begin{tabular}{|l|c|c|c|c|c|}
\hline \multicolumn{1}{|c|}{ Model } & $\begin{array}{c}\text { NFI } \\
\text { Delta1 }\end{array}$ & $\begin{array}{c}\text { RFI } \\
\text { rho1 }\end{array}$ & $\begin{array}{c}\text { IFI } \\
\text { Delta2 }\end{array}$ & $\begin{array}{c}\text { TLI } \\
\text { rho2 }\end{array}$ & CFI \\
\hline Default model & 0.996 & 0.982 & 1.001 & 1.004 & 1.000 \\
\hline Saturated model & 1.000 & & 1.000 & & 1.000 \\
\hline $\begin{array}{l}\text { Independence } \\
\text { model }\end{array}$ & 0.000 & 0.000 & 0.000 & 0.000 & 0.000 \\
\hline
\end{tabular}

PARSIMONY-ADJUSTED MEASURES

\begin{tabular}{|l|c|c|c|}
\hline \multicolumn{1}{|c|}{ Model } & PRATIO & PNFI & PCFI \\
\hline Default model & 0.200 & 0.199 & 0.200 \\
\hline Saturated model & 0.000 & 0.000 & 0.000 \\
\hline Independence model & 1.000 & 0.000 & 0.000 \\
\hline
\end{tabular}

NCP

\begin{tabular}{|l|c|c|c|}
\hline \multicolumn{1}{|c|}{ Model } & NCP & LO 90 & HI 90 \\
\hline Default model & 0.000 & 0.000 & 6.993 \\
\hline Saturated model & 0.000 & 0.000 & 0.000 \\
\hline Independence model & 455.301 & 388.384 & 529.628 \\
\hline
\end{tabular}

\section{FMIN}

\begin{tabular}{|l|c|c|c|c|}
\hline \multicolumn{1}{|c|}{ Model } & FMIN & F0 & LO 90 & HI 90 \\
\hline Default model & 0.006 & 0.000 & 0.000 & 0.025 \\
\hline Saturated model & 0.000 & 0.000 & 0.000 & 0.000 \\
\hline Independence model & 1.656 & 1.620 & 1.382 & 1.885 \\
\hline
\end{tabular}

RMSEA

\begin{tabular}{|l|c|c|c|c|}
\hline \multicolumn{1}{|c|}{ Model } & RMSEA & LO 90 & HI 90 & PCLOSE \\
\hline Default model & 0.000 & 0.000 & 0.112 & 0.646 \\
\hline $\begin{array}{l}\text { Independence } \\
\text { model }\end{array}$ & 0.403 & 0.372 & 0.434 & 0.000 \\
\hline
\end{tabular}

AIC

\begin{tabular}{|l|r|r|r|r|}
\hline \multicolumn{1}{|c|}{ Model } & AIC & BCC & BIC & CAIC \\
\hline Default model & 25.645 & 26.080 & & \\
\hline Saturated model & 28.000 & 28.507 & & \\
\hline $\begin{array}{l}\text { Independence } \\
\text { model }\end{array}$ & 473.301 & 473.446 & & \\
\hline
\end{tabular}

ECVI

\begin{tabular}{|l|c|c|c|c|}
\hline \multicolumn{1}{|c|}{ Model } & ECVI & LO 90 & HI 90 & MECVI \\
\hline Default model & 0.091 & 0.093 & 0.117 & 0.093 \\
\hline Saturated model & 0.100 & 0.100 & 0.100 & 0.101 \\
\hline $\begin{array}{l}\text { Independence } \\
\text { model }\end{array}$ & 1.684 & 1.446 & 1.949 & 1.685 \\
\hline
\end{tabular}

HOELTER

\begin{tabular}{|l|c|c|}
\hline \multicolumn{1}{|c|}{ Model } & HOELTER & HOELTER \\
& $\boldsymbol{0 . 0 5}$ & $\mathbf{0 . 0 1}$ \\
\hline Default model & 1024 & 1573 \\
\hline Independence model & 12 & 15 \\
\hline
\end{tabular}


As it is highlighted in figure 4 and 5 above, four predictive indicators were tested in the modified model and minimum was achieved for the model. Based on the goodness of fit statistics, it is evident that the overall model fit quite well to the data. This is because the estimated $\chi^{2}$ of $1.645(\mathrm{df}=2)$ is not large enough to reject the null hypothesis of a good fit at the .05 level ( $p<0.439)$. Additionally, the estimated Root Mean Square Error of Approximation (RMSEA) of $0.000(p<0.439)$ and the Comparative Fit Index (CFI) of 1.00 indicate that the modified model fits the data well.

The maximum likelihood estimates entailing the standardized regression estimates, squared multiple correlations, implied covariance and implied correlations obtained from AMOS graphics are summarized below. The standardized regression estimates which represent the factor loadings (i.e. indicator coefficients) associated with the arrows from latent variables to the respective indicator variables in the modified model are highlighted in table 10 below.

TABLE 9:STANDARDIZED REGRESSION ESTIMATES (FACTOR LOADINGS) FROM LATENT VARIABLE (LEADERSHIP STYLE) TO INDICATOR VARIABLES IN MODIFIED MODEL

\begin{tabular}{|l|c|c|c|}
\hline \multicolumn{1}{|c|}{$\begin{array}{c}\text { Indicator } \\
\text { Variables }\end{array}$} & $\begin{array}{c}\text { Indicator } \\
\text { Label in } \\
\text { Model }\end{array}$ & $\begin{array}{c}\text { Standardized } \\
\text { Regression } \\
\text { indicator coefficient }\end{array}$ & $\begin{array}{c}\text { Squared } \\
\text { Multiple } \\
\text { Correlations }\end{array}$ \\
\hline $\begin{array}{l}\text { Supervisors giving } \\
\text { employees full credit } \\
\text { for the work done. }\end{array}$ & BQ6 & 0.702 & 0.492 \\
\hline $\begin{array}{l}\text { Managers handling } \\
\text { employee issues very } \\
\text { well. }\end{array}$ & BQ7 & 0.857 & 0.735 \\
\hline $\begin{array}{l}\text { Managers taking care } \\
\text { of complaints } \\
\text { brought up by } \\
\text { employees. }\end{array}$ & BQ9 & 0.789 & 0.622 \\
\hline $\begin{array}{l}\text { Managers enhancing } \\
\text { employees' career } \\
\text { advancement into } \\
\text { specialist } \\
\text { departments or } \\
\text { management } \\
\text { positions. }\end{array}$ & BQ11 & 0.718 & 0.516 \\
\hline
\end{tabular}

The standardized regression estimates (indicator loading coefficients) for BQ6 (i.e. managers handling employee issues very well) is .702 $(\alpha=0.492)$. That for BQ7 (i.e. supervisors giving employees full credit for the work done) is 0.857 ( $\alpha=$ 0.735). For BQ9 (i.e. managers taking care of complaints brought up by employees) and BQ11 (i.e. managers enhancing employees' career advancement into specialist departments or management positions), the standardized regression estimates (indicator loading coefficients) are $0.789(\alpha=0.622)$ and $0.718(\alpha=0.516)$ respectively. All the estimated loadings for the indicators are significant in that; indicators should by convention, have loadings of 0.7 or higher on the latent variable (Schumacker \& Lomax, 2004) for them to be significant.

The implied covariance and correlations for all the variables are presented in table 11 and 12 below.
TABLE 11: IMPLIED COVARIANCE FOR ALL VARIABLES IN THE MODIFIED DEFAULT MODEL

\begin{tabular}{|c|c|c|c|c|c|}
\hline Variables & LS & BQ6 & BQ7 & BQ9 & BQ11 \\
\hline LS & 0.436 & & & & \\
\hline BQ6 & 0.399 & 0.741 & & & \\
\hline BQ7 & 0.517 & 0.472 & 0.832 & & \\
\hline BQ9 & 0.461 & 0.421 & 0.545 & 0.781 & \\
\hline BQ11 & 0.436 & 0.399 & 0.517 & 0.461 & 0.846 \\
\hline
\end{tabular}

TABLE 12:IMPLIED CORRELATIONS FOR ALL VARIABLES IN THE MODIFIED DEFAULT MODEL

\begin{tabular}{|c|c|c|c|c|c|}
\hline Variables & LS & BQ6 & BQ7 & BQ9 & BQ11 \\
\hline LS & 1.000 & & & & \\
\hline BQ6 & 0.702 & 1.000 & & & \\
\hline BQ7 & 0.857 & 0.602 & 1.000 & & \\
\hline BQ9 & 0.789 & 0.554 & 0.676 & 1.000 & \\
\hline BQ11 & 0.718 & 0.504 & 0.616 & 0.567 & 1.000 \\
\hline
\end{tabular}

\section{CONCLUSION}

The findings from this study have shown that employees of retail banks in Ghana have strong appreciation of some leadership actions at the workplace. Though this study tested as several indicators of leadership in the work environment of retail banks, the results showed that issues that has to do with the manager's competence in making decisions $(\mathrm{r}=0.651, \alpha=$ $0.424)$, as well as supervisors and employees understanding each other $(\mathrm{r}=0.807, \alpha=0.651)$ could not be viewed as strong leadership style indicator. From the analysis, other indicators that could not provide the basis for effective leadership in retail banks in Ghana include the following managerial actions: (i) noticing employees in good ways upon doing good jobs $(\mathrm{r}=$ $0.807, \alpha=0.651$ ); (ii) providing help to employees on hard problems ( $\mathrm{r}=0.665, \alpha=0.442$ ), (iii) giving good training to employees ( $r=0.610, \alpha=0.372)$, (iv) delegating work to staff members ( $\mathrm{r}=0.503, \alpha=0.253)$, (v) backing employees up with good administration ( $r=0.635, \alpha=0.404)$, (vi) ensuring that staff members acquire effective client-customer relationship skills $(r=0.475, \alpha=0.225)$, (vii) ensuring that staff members are fully trained in how to work with maximum effect $(r=0.559, \alpha=0.312$ ), (viii) providing staff with recognition, enhanced responsibility and, the possibility of increased pay and promotion $(r=0.688, \alpha=0.473)$, (ix) giving staff a feeling of personal satisfaction and achievement $(\mathrm{r}=$ $0.672, \alpha=0.451)$, ( $\mathrm{x}$ ) increasing the confidence, motivation and commitment of staff $(r=0.648, \alpha=0.420)$, and ensuring that staff members have full knowledge of the firm's products/services $(r=0.568, \alpha=0.322)$.

In summary, this study has therefore established that managers of retail banks in Ghana could be perceived by their employees as good leaders if they are perceived by the employees as giving them (i.e. employees) full credit for the work that they employees do at the workplace. Additionally, the managers perceived as handling employee issues very well and taking care of complaints brought up by employees, as well as putting in place systems for enhancing employees' career advancement into specialist departments or management positions are also perceived as good leaders. 


\section{ACKNOWLEDGMENT}

We wish to acknowledge the administrative support provided by Empi Baryeh and Selasie Agamah from the Office of Research, Innovation and Development at the University of Ghana, and also by our Research Assistants John Osei Yeboah and Augustina Ashie from the Department of Organization and Human Resource Management, University of Ghana Business School, Legon.

\section{REFERENCES}

[1] K.J. Mitchener and D.C. Wheelock, "Does the structure of banking markets affect economic growth? Evidence from U.S. State banking markets". Working Paper 2010-004E (January 2010. Revised August 2012). Federal Reserve Bank of St. Louis, Research Division: http://research.stlouisfed.org/wp/2010/2010-004.pdf (Accessed on 27 March, 2013).

[2] R. G. Rajan and L. Zinagales, "Financial dependence and growth", Am Econ Rev, vol. 88, no. 3, pp. 559-86, 1998.

[3] F. Allen, "The Market for Information and the Origin of Financial Intermediaries", J Financ Intermed, vol. 1, pp. 3-30, 1990.

[4] J.H. Boyd, C. Edward and E.C. Prescott, "Financial IntermediaryCoalitions", J Econ Theory, vol. 38, pp. 211-32, 1982.

[5] J. Greenwood and B. Jovanovic, "Financial development, growth, and the distribution of income", J Polit Econ, vol. 98, no. 5, pp. 1076-1107, 1990.

[6] A.K. Kashyap, G.R. Raguram and J.C. Stein, "Banks as liquidity providers: An explanation for the co-existence of lending and deposittaking", J Financ, vol. 57, no. 1, pp. 33-73, 2002.

[7] R.G. King and R. Levine, "Finance and growth: Schumpeter might be right", Q J Econ, vol. 108, pp. 717-738, 1993.

[8] C. Blankson, J.M.S. Cheng, and N. Spears, "Determinants of bank selection in USA, Taiwan and Ghana". Int J Bank Marketing, vol. 25, no. 7, pp. 469-489, 2007.

[9] N. Owusu-Frimpong, (2008) "An evaluation of customers perception and usage of rural community banks (RCBs) in Ghana" J Emerg Markets, vol. 3, no. 2, pp. 181-196, 2008.

[10] H.C. Koh, and E.H.Y. Boo. (2000). "The link between organizational ethics and job satisfaction: A study of managers in Singapore", J Bus Ethics, vol. 29, pp. 309-324, 2000.

[11] F.A. Russ, and K.M. McNeilly, "Links among satisfaction, commitment, and turnover intentions: The moderating effect of experience, gender and performance", J Bus Res, vol. 34, no. 1, pp. 57-65, 1995.

[12] B. Benkhoff, "Disentangling organisational commitment: the changes of the OCQ for research and policy", Pers Rev, vol. 26, no. 1, pp. 114-20, 1997.

[13] H. Laschinger, "The impact of workplace commitment, organizational trust on staff nurses' work satisfaction and organizational commitment", Health Care Manage R, vol. 26, no. 3, pp. 7-24, 2001.

[14] L. Williams, and J. Hazer, "Antecedents and consequences of satisfaction and commitment in turnover modes: a re-analysis using latent variables structural equation methods", J Appl Psychol, vol. 71, no. 2, pp. 219-31, 1986.

[15] H. Trice and J. Beyer, The Culture of Work Organization, Prentice-Hall, Englewood Cliffs, NJ, 1993.

[16] G. Hofstede, Culture's consequences: International differences in workrelated values. London: Sage, 1980.

[17] N. Cetorelli and M. Gambera, "Banking market structure, financial dependence, and growth: international evidence from industry data", J Financ, vol. 106, no. 2, pp. 617-48, 2001.

[18] E. Bonaccorsi di Patti, and G. Dell'Ariccia, "Bank Competition and Firm Creation", J Money Credit Bank, vol. 36, no. 2, pp. 225-52, 2004.

[19] S. Claessens and L. Laeven, "Financial dependence, banking sector competition, and economic growth", J Eur Econ Assoc, vol. 3, no. 1, pp. 179-207), 2005.
[20] I. Hoxha, "Big banks versus small banks: Good or bad for industries?" University of Houston working paper, 2009.

[21] N. Cetorelli and P. Strahan, "Finance as a barrier to entry: Bank competition and industry structure in local U.S. Markets", J Financ, vol. 61, no. 1, pp. 437-461, 2006.

[22] A.M. Adam, D. Agyapong and S. Asante, "Bank competition, stock market and economic growth in Ghana", Int J Bus Admin, vol. 2, no. 4, pp. 33-41, 2011.

[23] A.L. Kristof, "Person-organization fit: An integrative review of its conceptualizations, measurement, and implications", Pers Psychol, vol. 49, pp. 1-49, 1996.

\section{Creative Commons Attribution License 4.0 (Attribution 4.0 International, CC BY 4.0)}

This article is published under the terms of the Creative Commons Attribution License 4.0 https://creativecommons.org/licenses/by/4.0/deed.en_US 